Pesq. Vet. Bras. 37(7):691-696, julho 2017

DOI: $10.1590 / \mathrm{S} 0100-736 \mathrm{X} 2017000700007$

\title{
Frequência de genes codificadores de toxinas em Staphylococcus aureus isolados de leite de tanques expansão comunitários ${ }^{1}$
}

\begin{abstract}
Atzel Candido Acosta ${ }^{2 *}$, Sidney José dos Santos ${ }^{3}$, Laís Albuquerque ${ }^{2}$, Karla Danielle Almeida Soares ${ }^{4}$, Rinaldo Aparecido Mota $^{2}$ e Elizabeth Sampaio de Medeiros ${ }^{2}$

ABSTRACT.- Acosta A.C., Santos S.J., Albuquerque L., Soares K.D.A., Mota R.A. \& Medeiros E.S. 2017. [Frequency of toxin-encoding genes in Staphylococcus aureus isolated from community milk tanks.] Frequência de genes codificadores de toxinas em Staphylococcus aureus isolados de leite de tanques expansão comunitários. Pesquisa Veterinária Brasileira 37(7):691-696. Laboratório de Bacterioses dos Animais Domésticos, Departamento de Medicina Veterinária, Universidade Federal Rural de Pernambuco, Rua Dom Manoel de Medeiros s/n, Dois Irmãos, Recife, PE 52171-900, Brazil. E-mail: acabad80@gmail.com

The capacity of toxin production by Staphylococcus aureus in milk and dairy products is associated with food poisoning outbreaks. The objective of this research was to study the frequency of genes encoding staphylococcal enterotoxin (sea, seb, sed, seg, seh and sei) and $\alpha$ and $\beta$ hemolytic toxins ( $h l a$ and $h l b$ ) in S. aureus isolates from 53 milk samples from community tanks in the State of Alagoas, Brazil. Twenty-seven isolates (50.94\%) were identified as S. aureus by nuc gene amplification; $13 / 27$ isolates (48.1\%) were positive for at least one gene of the studied enterotoxins and the frequency of genes sea was $33.3 \%$, seh $18.5 \%$, sei $11.1 \%$ and sed $7.4 \%$; the $s e b$ and sec genes have not been identified in the bacteria. For the hemolytic toxins, $51.9 \%$ of isolates harbored both genes ( $h l a$ and $h l b$ ), the frequency of $h l a$ gene was $81.5 \%$ and $51.9 \%$ for the $h l b$ gene. The evaluated toxin-encoding gene frequency is high and constitutes a potential risk for public health, especially staphylococcal enterotoxin genes; because they are heat-stable enterotoxins and have been associated with food poisoning.
\end{abstract}

INDEX TERMS: Enterotoxin gene, PCR, superantigen genes, SE genes, milk.

RESUMO.- A capacidade de produção de toxinas pelo Staphylococcus aureus no leite e produtos derivados está relacionado com surtos de intoxicação alimentar. Objetivou-se nesta pesquisa, estudar a ocorrência de genes que codificam para enterotoxinas estafilocócicas (sea, seb, sed, seg, seh e sei) e toxinas $\alpha$ e $\beta$ hemolítica (hla e hlb) em S. aureus isolados de 53 amostras de leite de tanques expansão comunitários no Estado de Alagoas, Brasil. Foram identifica-

\footnotetext{
${ }^{1}$ Recebido em 28 de outubro de 2015.

Aceito para publicação em 21 de fevereiro de 2017.

${ }^{2}$ Laboratório de Bacterioses dos Animais Domésticos, Departamento de Medicina Veterinária, Universidade Federal Rural de Pernambuco (UFRPE), Rua Dom Manoel de Medeiros s/n, Dois Irmãos, Recife, PE 52171900, Brasil. *Autor para correspondência: acabad80@gmail.com

${ }^{3}$ Programa de Pós-Graduação em Zootecnia, Universidade Federal de Alagoas (UFAL), BR-104 Norte Km 85 s/n, Mata do Rolo, Rio Largo, AL 57100-000, Brasil.

${ }^{4}$ Programa de Pós-Graduação em Nutrição, UFAL, Av. Lorival Melo Mota s/n, Tabuleiro dos Martins, Maceió, AL 57072-900, Brasil.
}

dos 27 isolados $(50,94 \%)$ como $S$. aureus pela amplificação do gene nuc. $13 / 27$ isolados $(48,1 \%)$ foram positivos para pelo menos um gene das enterotoxinas estudadas, sendo as frequências dos genes sea $33,3 \%$, seh $18,5 \%$, sei $11,1 \%$ e sed 7,4\%; não entanto não foram identificados os genes seb e seg nestas bactérias. Para as toxinas hemolíticas, 51,9\% dos isolados portavam ambos genes (hla e $h l b$ ), sendo a frequência para o gene hla de $81,5 \%$ e para o gene $h l b$ de $51,9 \%$. A frequência de genes das toxinas avaliadas é alta o que constitui um risco potencial para a saúde pública em especial, as enterotoxinas por serem termoestáveis e estarem asssociados com surtos de intoxicação alimentar.

TERMOS DE INDEXAÇÃO: Gene enterotoxina, PCR, genes superantígenos, genes $\mathrm{SE}$, leite.

\section{INTRODUÇÃO}

Os alimentos de origem animal e em especial o leite e os produtos derivados estão associados com a propagação de 
doenças alimentárias (Reis et al. 2013). Staphylococcus aureus é considerado mundialmente um dos mais importantes patógenos causadores de intoxicação alimentar (Cretenet et al. 2011).

0 leite é um meio propício para o crescimento de $S$. aureus e a produção de enterotoxinas estafilocócicas (staphylococcal enterotoxins SEs), o que pode estar influenciado por fatores como a temperatura, $\mathrm{pH}$, concentração de sal $(\mathrm{NaCl})$, atividade da água e arejamento. Sendo que, para produzir intoxicações alimentares a contagem de S. aureus deve atingir no mínimo $2.9 \times 10^{5} \mathrm{UFC} / \mathrm{g}$ (Necidová et al. 2009).

O grupo mais comum de SEs está formado por 5 sorotipos (SEA, SEB, SEC, SED e SEE) que são responsáveis por 95\% das intoxicações estafilocócicas (Bergdoll \& Lee Wong 2006), mas nos últimos anos foram descritos novos serotipos completando un total de 21 (Hennekinne et al. 2010). As SEs são solúveis em água e altamente resistentes à atividade das maiorias das enzimas proteolíticas, tais como tripsina e pepsina o que mantém sua atividade biológica no tubo digestivo após ingestão (Cretenet et al. 2011). Além disso, as SEs também mantêm suas atividades biológicas após ser submetida a altas temperaturas (pasteurização) (Asao et al. 2003).

Por outro lado, a toxina $\alpha$ hemolítica (Hla) ou $\alpha$ toxina, como também é conhecida, é um monômero solúvel em água (Berube \& Wardenburg 2013), e é considerada a mais proeminente citotoxina produzida pelo $S$. aureus pela ampla gama de células do hospedeiro contra as quais é capaz de atuar. A toxina $\beta$ hemolítica ( $\mathrm{Hlb}$ ) é produzida pela maioria dos isolados de $S$. aureus obtidos de amostras de leite de bovinos com mastites e de infecções crônicas na pele em humanos (Aarestrup et al. 1999). Além disso, a Hlb apresenta uma relativa estabilidade frente a inativação por altas temperaturas, sendo termoestável abaixo de $90^{\circ} \mathrm{C}$ durante 30min (Singh et al. 2014), o que tem uma importante implicação para a saúde pública.

A presença $S$. aureus no leite é uma preocupação para saúde pública pela capacidade de produzir toxinas termoestáveis, contudo objetivou-se com este estudo detectar a frequência de genes que codificam para enterotoxinas estafilocócicas e toxinas $\alpha$ e $\beta$ hemolítica em Staphylococcus aureus isolados de leite de tanques de expansão comunitários no Estado de Alagoas, Brasil.

\section{MATERIAL E MÉTODOS}

Foram coletadas 53 amostras de leite cru, provenientes de tanques de expansão de cooperativas de produtores de leite do estado de Alagoas, em 23 municípios pertencentes às três mesorregiões do estado (Agreste Alagoano, Leste Alagoano e Sertão Alagoano) (Fig.1). Todas as amostras foram imediatamente transportadas ao Laboratório de Inspeção de Leite e Derivados da Universidade Federal de Alagoas, Viçosa-AL em caixas térmicas, mantendo uma temperatura de transporte entre $4-8^{\circ} \mathrm{C}$.

Para a realização da cultura primária, uma alíquota $(0,5 \mu \mathrm{L})$ de cada amostra foi semeada pela técnica de estrias por esgotamento em Agar Sangue de ovino a $5 \%$ e incubados a $37^{\circ} \mathrm{C}$, realizando-se leituras às 24, 48 e 72 horas. Foram avaliadas as características macroscópicas e microscópicas (morfo-tintoriais) das colônias utilizando-se a técnica de Gram. Testes de catalase e coagulase fo- ram realizados para a identificação de Staphylococcus coagulase positiva (SCP) (Saei et al. 2009); utilizou-se como controle positivo na pesquisa a cepa $S$. aureus ATCC 29213.

Antes de serem usadas na extração do DNA, as cepas foram recém-cultivas em caldo cérebro coração (Merck), sendo incubadas por 12 horas a $37^{\circ} \mathrm{C}$. A extração do DNA foi realizada a partir das culturas bacterianas utilizado-se o kit comercial Wizard $₫ \mathrm{Ge}$ nomic DNA Purification (Promega), seguindo as recomendações do fabricante.

O diagnóstico de Staphylococcus aureus foi realizado utilizando-se a técnica de reação em cadeia da polimerase (PCR) para amplificar o gene nuc que é específico para esta espécie (Brakstad et al. 1992; Kim et al. 2001). A amplificação do gene nuc partiu de um par de iniciador desenhados para este estudo (nuc_F e nuc_R) (Quadro 1), permitindo revelar um único fragmento amplificado com um tamanho de aproximadamente $296 \mathrm{pb}$.

Os oligonucleotídeos empregados na pesquisa dos genes que codificam as enterotoxinas estafilocócicas e toxinas $\alpha$ e $\beta$ hemolí-

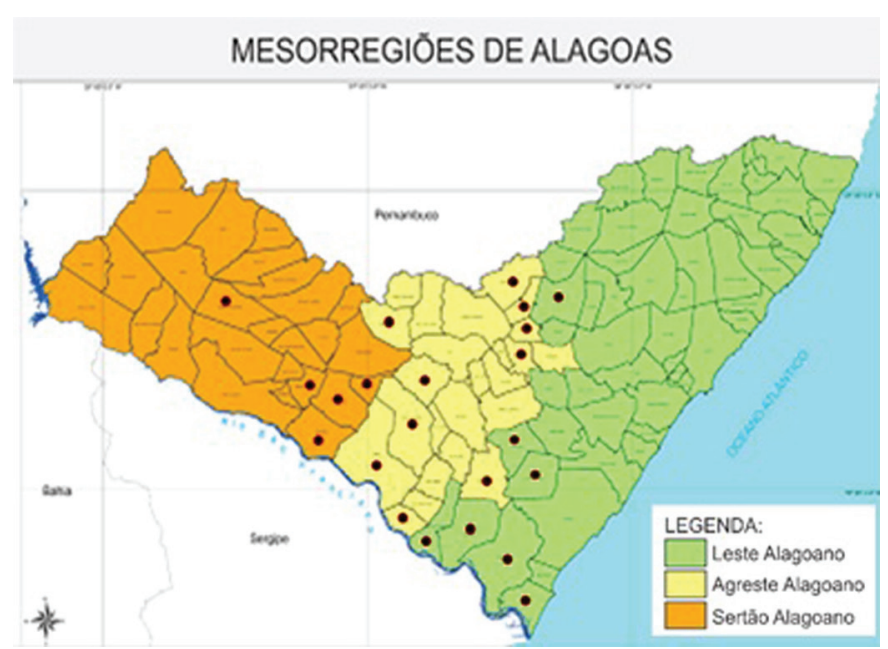

Fig.1. Mapa do Estado de Alagoas, Brasil. Distribuição dos municípios que participaram da coleta de amostras de leite de tanques expansão comunitários.

Quadro 1. Oligonucleotídeos utilizados para detecção dos genes nuclease, enterotoxinas estafilocócicas e toxinas $\alpha$ e $\beta$ hemolítica

\begin{tabular}{|c|c|c|c|c|}
\hline $\begin{array}{l}\text { Gene } \\
\text { alvo }\end{array}$ & Nome & Oligonucleotídeo $\left(5^{\prime}-3^{\prime}\right)$ & $\begin{array}{l}\text { Fragmento } \\
\text { amplificado }\end{array}$ & Ta $(\mathrm{oC})^{*}$ \\
\hline nuc & $\begin{array}{l}\text { nuc_F } \\
\text { nuc_R }\end{array}$ & $\begin{array}{l}\text { GGTTCTGAAGATCCAACAGTAT } \\
\text { GCTAAGCCACGTCCATATTTA }\end{array}$ & $296 \mathrm{pb}$ & 61 \\
\hline sea & $\begin{array}{l}\text { sea_F } \\
\text { sea_R }\end{array}$ & $\begin{array}{l}\text { CCGAAGGTTCTGTAGAAGTATG } \\
\text { GCTTGTATGTATGGTGGTGTA }\end{array}$ & $269 \mathrm{pb}$ & 55 \\
\hline seb & $\begin{array}{l}\text { seb_F } \\
\text { seb_R }\end{array}$ & $\begin{array}{l}\text { CCCGTTTCATAAGGCGAGTT } \\
\text { ACGTAGATGTGTTTGGAGCTAAT }\end{array}$ & $314 \mathrm{pb}$ & 57 \\
\hline sed & $\begin{array}{l}\text { sed_F } \\
\text { sed_R }\end{array}$ & $\begin{array}{l}\text { GTCACTCCACACGAAGGTAATAA } \\
\text { GAGACTTTAGACCCATCAGAAGAA }\end{array}$ & $255 \mathrm{pb}$ & 55 \\
\hline seg & $\begin{array}{l}\text { seg_F } \\
\text { seg_R }\end{array}$ & $\begin{array}{l}\text { GCCAGTGTCTTGCTTTGTAATC } \\
\text { GAATGCTCAACCCGATCCTAA }\end{array}$ & $491 \mathrm{pb}$ & 56 \\
\hline seh & $\begin{array}{l}\text { seh_F } \\
\text { seh_R }\end{array}$ & $\begin{array}{l}\text { CACATCATATGCGAAAGCAGAAG } \\
\text { CCCAAACATTAGCACCAATCAC }\end{array}$ & $365 \mathrm{pb}$ & 60 \\
\hline sei & $\begin{array}{l}\text { sei_F } \\
\text { sei_R }\end{array}$ & $\begin{array}{l}\text { AGGCAGTCCATCTCCTGTATAA } \\
\text { TGCTCAAGGTGATATTGGTGTAG }\end{array}$ & $568 \mathrm{pb}$ & 55 \\
\hline hla & $\begin{array}{l}\text { hla_F } \\
\text { hla_R }\end{array}$ & $\begin{array}{c}\text { CTGTAGCGAAGTCTGGTGAAA } \\
\text { CGGCCTTATTGGTGCAAATG }\end{array}$ & $293 \mathrm{pb}$ & 62 \\
\hline hlb & $\begin{array}{l}\text { hlb_F } \\
\text { hlb_R }\end{array}$ & $\begin{array}{l}\text { GCCAAAGCCGAATCTAAGAAAG } \\
\text { ATCATGTCCAGCACCACAA }\end{array}$ & $\mathrm{ob}$ & 60 \\
\hline
\end{tabular}

* Temperatura de alinhamento. 
tica são apresentados no Quadro 1; cada reação revelou um único fragmento amplificado com os tamanhos respectivos. A reação de PCR foi realizada num volume total de $25 \mu \mathrm{L}$ em tubos de $0,2 \mathrm{~mL}$, contendo na mistura PCR buffer $(10 \mathrm{mM}$ Tris- $\mathrm{HCl}, \mathrm{pH} 9.0 ; 50 \mathrm{mM}$ $\mathrm{KCl}$ e $0.1 \%$ Triton $\mathrm{X}-100), 1,5 \mathrm{mM} \mathrm{MgCl}, 250 \mu \mathrm{M}$ de cada nucleotídeo, $0,5 \mu \mathrm{M}$ de cada um dos iniciadorés específicos para cada reação, 1,5U de Taq DNA Polimerase (PROMEGA), 20 ng de DNA e completou-se o volume final com água destilada. Nos casos de dos genes nuc, seb, sec e sed as concentrações de $\mathrm{MgCl}$ usados na reação foram de $3 \mathrm{mM}$.

As condições de amplificação consistiram em: 5 min a $94^{\circ} \mathrm{C}$ na etapa de desnaturação, 32 ciclos de $1 \mathrm{~min}$ a $94^{\circ} \mathrm{C}, 1 \mathrm{~min}$ com a temperatura de alinhamento (Quadro 1 ), $1 \mathrm{~min}$ a $72^{\circ} \mathrm{C}$, e uma extensão final a $72^{\circ} \mathrm{C}$ durante $5 \mathrm{~min}$. A exceção do gene sea onde foram realizados 40 ciclos de $1 \mathrm{~min}$ a $94^{\circ} \mathrm{C}, 1 \mathrm{~min}$ a $55^{\circ} \mathrm{C}, 1 \mathrm{~min}$ a $72^{\circ} \mathrm{C}$.

Para a visualização os produtos amplificados foram submetidos à eletroforese em gel de agarose a $2 \%$, tampão Tris-Acetato-EDTA (TAE) $(0,5 \mathrm{X})$ com corante Blue Green Loading Dye I (LGC Biotecnologia) utilizando $0,3 \mu \mathrm{L}$ por cada $10 \mu \mathrm{L}$ de produto amplificado e visualizados sob iluminação ultravioleta (UV).

\section{RESULTADOS}

Foram identificados $27(50,94 \%)$ isolados como Staphylococcus aureus pela amplificação de um fragmento de $296 \mathrm{pb}$ do gene nuclease (nuc) (Fig.2). As frequências dos genes das enterotoxinas estudadas apresenta-se de forma reduzida (Quadro 2), sendo os genes mais frequentemente encontrados neste estudo a sea com 9 isolados de 27 (33,33\%) com um único fragmento amplificado de 269 pb (Fig.3A), seguido por seh $5 / 27$ (18,52\%) com um fragmento amplificado de 365pb (Fig.3C), sei 3/27 (11,11\%) com um fragmento amplificado de 568pb (Fig.3D) e finalmente sed com $2 / 27(7,41 \%)$ com um fragmento amplificado de $255 \mathrm{pb}$ (Fig.3B). Os genes que codifican para as enterotoxinas seb e seg não foram encontrados nos isolados estudados.

A frequência dos genes hla e $h l b$ nos isolados de $S$. $a u$ reus avaliados neste estudo foram relativamente altas $81,48 \%$ e $51,85 \%$, respectivamente (Quadro 2). 0 fragmento amplificado para o gene hla foi de 293pb (Fig.4A) e de $495 \mathrm{pb}$ para o gene hlb (Fig.4B).

As frequências das combinações dos genes enterotoxinas estafilocócicas e toxinas $\alpha$ e $\beta$ hemolíticasão apresentadas no Quadro 3. Foram encontradas 14 combinação, onde a mais frequente $(33,33 \%)$ foi de isolados portadores dos genes de hemolisina (hla e $h l b$ ) e ausência dos genes que codificam para as enterotoxinas estafilocócica. A segunda combinação mais frequente com $12,5 \%$ dos isolados portadores do gene hla e ausência dos genes das enterotoxinas. Somente 2 isolados não portavam genes enterotoxinas estafilocócicas e toxinas $\alpha$ e $\beta$ hemolíticas.

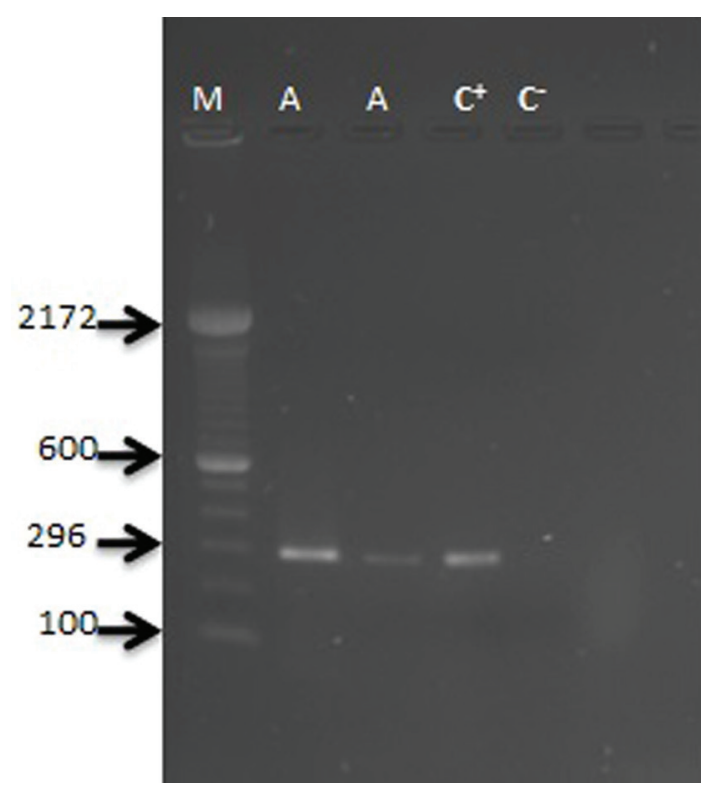

Fig.2. Amplificação do fragmento do gene nuc de Staphylococcus aureus isolados de amostras de leite cru. Linha M: marcador de peso molecular 100pb (Invitrogen); Linha A: amostras testadas; Linha $\mathrm{C}^{+}$: controle positivo; Linha C: controle negativo.

Quadro 2. Frequência de genes que codificam para enterotoxinas estafilocócicas e toxinas $\alpha$ e $\beta$ hemolítica em isolados de Staphylococcus aureus de amostras de leite cru $(n=27)$

\begin{tabular}{lcc}
\hline Genes & Freq. Abso.* & Freq. Relat. $(\%)^{* *}$ \\
\hline sea & 9 & 33,33 \\
seb & 0 & 0,00 \\
sed & 2 & 7,41 \\
seg & 0 & 0,00 \\
seh & 5 & 18,52 \\
sei & 3 & 11,11 \\
hla & 22 & 81,48 \\
hlb & 14 & 51,85
\end{tabular}

* Frequência Absoluta, ** Frequência Relativa.
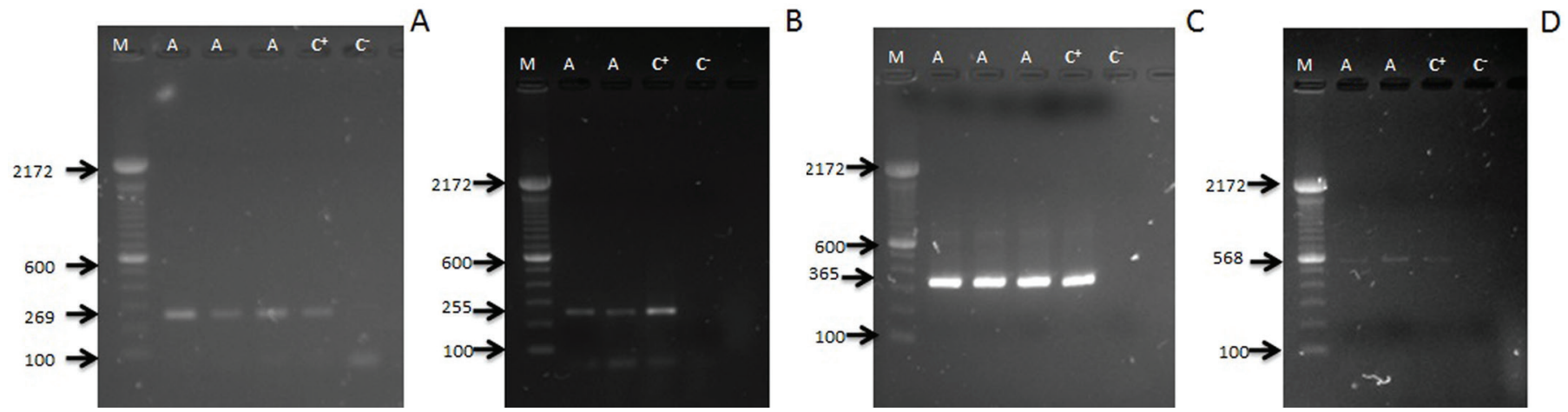

Fig.3. Amplificação dos fragmentos dos genes que codificam para enterotoxinas estafilocócicas em isolados de Staphylococcus aureus obtidos de amostras de leite cru. A sea, B sed, C seh e D sei. Linha M: marcador de peso molecular 100pb (Invitrogen); Linha A: amostras testadas; Linha $\mathrm{C}^{+}$: controle positivo; Linha $\mathrm{C}^{-}$: controle negativo. 


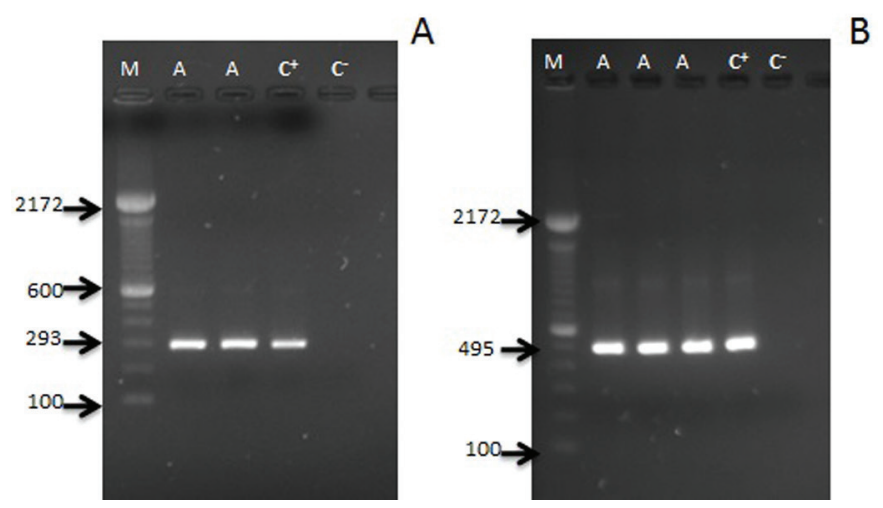

Fig.4. Amplificação dos fragmentos dos genes que codificam para as toxinas $\alpha$ e $\beta$ hemolítica em isolados de $S$. aureus obtidos de amostras de leite cru. A hla e B hlb. Linha M: marcador de peso molecular 100pb (Invitrogen); Linha A: amostras testadas; Linha $\mathrm{C}^{+}$: controle positivo; Linha C:- controle negativo.
Quadro 3. Frequência das 14 combinações dos genes enterotoxinas estafilocócicas e toxinas $\alpha$ e $\beta$ hemolítica

\begin{tabular}{ccccccccc}
\hline sea & seb & sed & seg & seh & sei & hla & hlb & Freq. (\%)* \\
\hline- & - & - & - & - & - & + & + & 33,33 \\
- & - & - & - & - & - & + & - & 12,50 \\
+ & - & - & - & + & - & + & + & 4,17 \\
+ & - & - & - & + & - & + & - & 4,17 \\
+ & - & - & - & - & + & + & + & 4,17 \\
+ & - & - & - & - & + & + & - & 4,17 \\
+ & - & - & - & - & + & - & - & 4,17 \\
+ & - & - & - & - & - & + & + & 8,33 \\
+ & - & - & - & - & - & + & - & 4,17 \\
+ & - & - & - & - & - & - & - & 4,17 \\
- & - & + & - & + & - & + & + & 4,17 \\
- & - & + & - & - & - & + & - & 4,17 \\
- & - & - & - & + & - & + & + & 4,17 \\
- & - & - & - & + & - & + & - & 4,17
\end{tabular}

*Frequência Relativa.

Quadro 4. Frequência relativa dos genes que codifica para as enterotoxinas estafilocócicas em estudos realizados no Brasil

\begin{tabular}{|c|c|c|c|c|c|c|c|c|c|c|c|}
\hline Estados & Referências & & sea & $s e b$ & $\sec$ & sed & see & seg & seh & sei & sej \\
\hline \multirow[t]{4}{*}{ São Paulo } & (Rall et al. 2008) & S. aureus & $41 \%$ & $7,7 \%$ & $20 \%$ & $12,8 \%$ & $5,1 \%$ & $28,2 \%$ & $7,7 \%$ & $25,6 \%$ & $7,7 \%$ \\
\hline & (Guimarães et al. 2013) & SCP* & $11,8 \%$ & $5,5 \%$ & $6,3 \%$ & $2,4 \%$ & & & & & \\
\hline & & $\mathrm{SCN}^{* *}$ & $57,3 \%$ & $12 \%$ & $18,7 \%$ & $12 \%$ & & & & & \\
\hline & (Rall et al. 2014) & S. aureus & $53,33 \%$ & $0 \%$ & $13,33 \%$ & $0 \%$ & $6,67 \%$ & $46,67 \%$ & $26,67 \%$ & $46,67 \%$ & 13,33 \\
\hline \multirow[t]{3}{*}{ Minas Gerais } & (Veras et al. 2008) & SCP & $45,45 \%$ & $50 \%$ & $0 \%$ & $0 \%$ & & & & & \\
\hline & & SCN & $37,5 \%$ & $0 \%$ & $25 \%$ & $12,5 \%$ & & & & & \\
\hline & (Dias et al. 2011) & S. aureus & $60 \%$ & $37,9 \%$ & $6,9 \%$ & & & & & & \\
\hline \multirow[t]{2}{*}{ Pernambuco } & (Almeida et al. 2013) & S. aureus & $0 \%$ & $0 \%$ & $44,10 \%$ & $0 \%$ & $0 \%$ & & & & \\
\hline & (Silveira-Filho et al. 2014) & S. aureus & $0 \%$ & $0 \%$ & $0 \%$ & $0 \%$ & $0 \%$ & $72,30 \%$ & $29,80 \%$ & $29,80 \%$ & $21,30 \%$ \\
\hline Paraíba & (Ferreira et al. 2014) & S. aureus & $0 \%$ & $0 \%$ & $16,67 \%$ & $0 \%$ & $0 \%$ & $0 \%$ & $0 \%$ & $2,78 \%$ & \\
\hline
\end{tabular}

* Staphylococcus coagulase positiva (SCP), ** Staphylococcus coagulase negativa (SCN).

\section{DISCUSSÃO}

A amplificação de um fragmento do gene nuc é considerado um método rápido e sensível para o diagnóstico de Staphylococcus aureus (Brakstad et al. 1992). A sensibilidade da técnica pode ser influenciada pela presença de agentes inibitórios da PCR, por exemplo o $\mathrm{Ca}^{2+}$ é um importante inibidor da reação e pode reduzir a sensibilidade do diagnóstico para $65 \%$ quando o processo de extração de DNA é feito diretamente do leite (Kim et al. 2001). Nesta pesquisa, os efeitos negativos dos inibidores da PCR presentes no leite foram eliminados, pois o processo de extração do material genético foi feito a partir das colônias puras do microrganismo. Estudos recentes demonstram que a sensibilidade da PCR supera os métodos de cultura e permite a identificação do patógeno com alta especificidade e em poucas horas (Cantekin et al. 2015). A maioria dos isolados SCP pertencem a espécie $S$. aureus (Krewer et al. 2014) fato que também foi observado em nosso estudo onde o 69,2\% dos isolados SCP foram identificados como S. aureus, mas também existem isolados de $S$. aureus negativos à prova de coagulase em tubo (Lange et al. 2015).

Os genes que codifican as enterotoxinas estafilocócicas (se) encontram-se em diferentes suportes genéticos (plasmídeos, fagos e ilhas de patogenicidade), todos estes suportes são elementos genéticos móveis (Le Loir et al. 2003). Se compararmos as frequências dos genes se relatados em diferentes pesquisas no mundo observa-se que existe dife- rença entre países e inclusive entre regiões de um mesmo país, fato que fortalece o postulado defendido por (Liu et al. 2014), onde a ocorrência de fatores de virulência pode variar entre as estirpes de $S$. aureus associados a casos de mastites nas diferentes localizações geográficas.

As frequências dos genes que codificam para as enterotoxinas estafilocócicas em estudos realizados no Brasil são apresentadas de forma resumida no Quadro 4. Em nosso estudo as maiores frequências observadas foram do gene sea, altas frequências foram observadas nos estudos realizados no sudeste (Rall et al. 2008, Veras et al. 2008, Dias et al. 2011, Guimarães et al. 2013, Rall et al. 2014), chama a atenção que este gene tem alta frequência também em isolados SCN estudados nesta região. Não entanto, em estudos realizados na região nordeste, o gene que codifica para esta enterotoxina não foi encontrado nos isolados de $S$. aureus estudados (Almeida et al. 2013, Ferreira et al. 2014, Silveira-Filho et al. 2014). Estudos de expressão do gene sea advertem da alta frequência de expressão do mesmo $\geq 60 \%$ (Veras et al. 2008) e 100\% (Rall et al. 2014), pelo que a presencia do gene em isolados obtidos de alimentos continue um risco para a saúde pública.

Estudos geograficamente distantes como os realizados nas regiões de Inner Mongolia e Shanghai na China, onde foram avaliados 283 isolados de $S$. aureus, observou-se que o gene sea esteve presente em $36 \%$ dos isolados, sendo o gene de maior frequência (Wang et al. 2009). Na região do 
noroeste da China, em estudos de epidemiologia molecular de $S$. aureus isolados de surto de intoxicação alimentar, a frequência do gene sea foi de $57.1 \%$ (Li et al. 2015) e no Irã, a frequência deste gene foi de 30,7\% (Nazari et al. 2014).

Não foram encontrados isolados portadores do gene seb neste estudo. As frequências descritas em estudos realizados por Rall et al. (2008), Guimarães et al. (2013) e Rall et al. (2014) são baixas ou cero (Quadro 4). Nos estudos realizados no nordeste tão pouco foram encontrados isolados de $S$. aureus portadores deste gene (Almeida et al. 2013, Ferreira et al. 2014, Silveira-Filho et al. 2014). Em outros países também são descritos estudos onde a frequência deste gene é cero nos isolados de $S$. aureus circulantes, por exemplo na Itália (Perillo et al. 2012, Ruaro et al. 2013), Turquia (Günaydın et al. 2011) e no Estado da Califórnia (USA) (Cenci-Goga et al. 2003). A toxina SEB é considerada uma arma biológica e sua inalação pode provocar lesões pulmonares e insuficiência respiratória (Rao et al. 2014). Outro aspecto de especial interesse é que em estudos onde se avalia a expressão do gene seb observou-se que $100 \%$ dos portadores do gene produziam a toxina SEB (Carfora et al. 2015).

A frequência do gene sed observada em nosso estudo foi relativamente baixa $(7,41 \%)$. Este gene não foi identificado em isolados de $S$. aureus nos estudos realizados no nordeste (Almeida et al. 2013, Ferreira et al. 2014, Silveira-Filho et al. 2014). Nas pesquisas realizadas no sudeste (Quadro 4) são apresentados valores baixos nas frequências deste gem e (Rall et al. 2008, Veras et al. 2008, Guimarães et al. 2013) ou não foi encontrado nos isolados avaliados por Rall et al. (2014). Internacionalmente as frequências descritas para este gene também são baixas, por exemplo na Itália isolados de $S$. aureus no leite ou derivados do leite nas espécies bovina, caprina, ovina e bubalina apresentam frequências do gene sed de 20\% (Carfora et al. 2015) e no Irã foram relatadas frequências de 15,4\% para este gene (Nazari et al. 2014).

Neste estudo não foi identificado o gene seg nos isolados de $S$. aureus avaliados, assim como no estudo de $S$. aureus isolados de cabras com mastite no Estado da Paraíba (Ferreira et al. 2014). Comparando este resultado com os obtidos em Pernambuco por Silveira-Filho et al. (2014) observam-se grandes diferenças, pois o 72,3\% dos isolados portavam o gene seg e na região do sudeste Rall et al. (2014) identificaram o gene seg em $50 \%$ dos isolados de $S$. aureus avaliados (Quadro 4).

A frequência do gene seh obtida neste estudo foi de $18,5 \%$, resultado inferior aos obtidos por Rall et al. (2014) e Silveira-Filho et al. (2014), sendo as frequências de 26,67\% e 29,8\% respetivamente (Quadro 4). No Estado da Paraíba, o gene que codifica para essa toxina não foi detectado (Ferreira et al. 2014). Internacionalmente também não foi encontrado o gene seh em isolados de $S$. aureus causadores de mastite bovina na Turquia (Günaydın et al. 2011) em leite de ovelhas na Itália (Perillo et al. 2012) ou são relatadas frequência baixa $(1,7 \%)$ na Bélgica (Ote et al. 2011).

A frequência do gene que codifica para a toxina sei neste estudo foi de 11,1\%. No Nordeste do Brasil (Quadro 4), as frequências deste gene foram entre baixa e média (Ferreira et al. 2014, Silveira-Filho et al. 2014) como valores de 2,8\% e $29,8 \%$ respectivamente. No Sudeste o $46,7 \%$ dos isola- dos de $S$. aureus de casos de mastites carregam este gene (Rall et al. 2014). No âmbito internacional também foram reportadas frequências com valores baixos como é o caso do estudo realizado no Irã $(3,8 \%)$ (Nazari et al. 2014) e valores médios na China (31,8\%) (Wang et al. 2009) e México (31,5\%) (Salgado-Ruiz et al. 2014).

Os genes hla e hlb nos isolados de S. aureus avaliados neste estudo apresentaram frequências relativamente altas de $81,5 \%$ e 51,9\%, respectivamente. A frequência destes genes no estudo desenvolvido na Paraíba por Almeida et al. (2013) foi de 77,3\% (hla) e 27,5\% (hlb). Também são reportadas altas frequências em pesquisas internacionais. Na Bélgica, as frequências foram de 98,7\% (hla) e 99,1\% (hlb) (Ote et al. 2011); na Indonésia, as frequências foram de $84 \%$ (hla) e $16 \%$ ( $h l b$ ) (Salasia et al. 2011) e na China foram encontradas frequências de $85 \%$ para a hla e $82 \%$ para a $h l b$ (Yang et al. 2012). Observou-se que a toxina Hla do $S$. aureus provoca a morte de um número significativo de eosinófilos in vitro (Prince et al. 2012). Por outro lado, a toxina Hlb é dependente de $\mathrm{Mg}^{2+}$ e degrada a esfingomielina (tipo de esfingolipídeo) presente nas membranas dos eritrócitos, leucócitos, neurônios e outros tipos de células, provocando assim a ruptura da membrana celular (Dinges et al. 2000). Um terço dos isolados $(33,33 \%)$ carregam ambos genes de hemolisina (hla e hlb). A presença e possível expressão destes genes permite ao microrganismo a evasão do sistema imune do hospedeiro (Dinges et al. 2000, Prince et al. 2012), assim como auxilia no processo de obtenção de nutrientes (Huseby et al. 2007).

\section{CONCLUSÕES}

Existe uma alta frequência de isolados de Staphylococcus aureus positivos para genes de enterotoxinas estafilocócicas (sea e seh) no leite cru dos tanques de expansão.

Mesmo precisando de posteriores estudos de expressão gênica das toxinas e de contagem de UFC, o fato de serem genes que codificam para toxinas termoestáveis faz com que este constitua um risco para a saúde pública.

Observou-se uma alta frequência dos genes que codificam para as toxinas hemolíticas (hla e $h l b$ ). A alta porcentagem de isolados positivos para estes fatores de virulência aumenta a patogenicidade das cepas e consequentemente incrementa a capacidade do microrganismo de colonizar o hospedeiro.

Agradecimentos.- Os autores agradecem a Fundação de Amparo à Ciência e Tecnologia do Estado de Pernambuco (FACEPE) por conceder a bolsa de estudo de pós-graduação (IBP-0439-5.05/12) e ao Conselho Nacional de Desenvolvimento Científico e Tecnológico (CNPq) pelo suporte financeiro (442746/2014-8).

\section{REFERÊNCIAS}

Aarestrup F.M., Larsen H., Eriksen N., Elsberg C. \& Jensen N. 1999. Frequency of $\alpha$-and $\beta$-haemolysin in Staphylococcus aureus of bovine and human origin. Acta Pathol. Microbiol. Immunol. Scand. 107:425-430.

Almeida L.M., De Almeida M.Z.P., Mendonça C.L.D. \& Mamizuka E.M. 2013. Comparative analysis of agr groups and virulence genes among subclinical and clinical mastitis Staphylococcus aureus isolates from sheep flocks of the Northeast of Brazil. Braz. J. Microbiol. 44:493-498.

Asao T., Kumeda Y., Kawai T., Shibata T., Oda H., Haruki K., Nakazawa H. \& Kozaki S. 2003. An extensive outbreak of staphylococcal food poisoning due to low-fat milk in Japan: estimation of enterotoxin A in the incriminated milk and powdered skim milk. Epidemiol. Infect. 130:33-40. 
Bergdoll M.S. \& Lee Wong A.C. 2006. Staphylococcal intoxications, p523562. In: Rieman H.P. \& Cliver D.O. (Eds), Foodborne Infections and Intoxications. Elsevier, California.

Berube B. \& Wardenburg J. 2013. Staphylococcus aureus $\alpha$-toxin: nearly a century of intrigue. Toxins 5:1140-1166.

Brakstad O., Aasbakk K. \& Maeland J.A. 1992. Detection of Staphylococcus aureus by polymerase chain reaction amplification of the nuc gene. J. Clin. Microbiol. 30:1654-1660.

Cantekin Z., Ergün Y. \& Doğruer G. 2015. Comparison of PCR and culture methods for diagnosis of subclinical mastitis in dairy cattle. Kafkas Universitesi Veteriner Fakultesi Dergisi 21:277-282.

Carfora V., Caprioli A., Marri N., Sagrafoli D., Boselli C., Giacinti G., Giangolini G., Sorbara L., Dottarelli S., Battisti A. \& Amatiste S. 2015. Enterotoxin genes, enterotoxin production, and methicillin resistance in Staphylococcus aureus isolated from milk and dairy products in Central Italy. Int. Dairy J. 42:12-15.

Cenci-Goga B., Karama M., Rossitto P., Morgante R. \& Cullor J. 2003. Enterotoxin production by Staphylococcus aureus isolated from mastitic cows. J. Food Protect. 66:1693-1696.

Cretenet M., Even S. \& Le Loir Y. 2011. Unveiling Staphylococcus aureus enterotoxin production in dairy products: a review of recent advances to face new challenges. Dairy Sci. Technol. 91:127-150.

Dias N., Silva D., Oliveira D., Fonseca Junior A., Sales M. \& Silva N. 2011. Detection of genes of Staphylococcus aureus, enterotoxins and methicillin resistance in milk. Arq. Bras. Med. Vet. Zootec. 63:1547-1552.

Dinges M.M., Orwin P.M. \& Schlievert P.M. 2000. Exotoxins of Staphylococcus aureus. Clin. Microbiol. Rev. 13:16-34.

Ferreira D.H., Carvalho M.G.X., Nardelli M.J., Sousa F.G. \& Oliveira C.J. 2014. Occurrence of enterotoxin-encoding genes in Staphylococcus aureus causing mastitis in lactating goats. Pesq. Vet. Bras. 34:633-636.

Guimarães F.D.F., Nóbrega D.B., Richini-Pereira V.B., Marson P.M., Figueiredo Pantoja J.C. \& Langoni H. 2013. Enterotoxin genes in coagulase-negative and coagulase-positive staphylococci isolated from bovine milk. J. Dairy Sci. 96:2866-2872.

Günaydın B., Aslantaş Ö. \& Demir C. 2011. Detection of superantigenic toxin genes in Staphylococcus aureus strains from subclinical bovine mastitis. Trop. Anim. Health Prod. 43:1633-1637.

Hennekinne J.-A., Ostyn A., Guillier F., Herbin S., Prufer A.-L. \& Dragacci S. 2010. How should staphylococcal food poisoning outbreaks be characterized? Toxins 2:2106-2116.

Huseby M., Shi K., Brown C.K., Digre J., Mengistu F., Seo K.S., Bohach G.A., Schlievert P.M., Ohlendorf D.H. \& Earhart C.A. 2007. Structure and biological activities of beta toxin from Staphylococcus aureus. J. Bacteriol. 189:8719-8726.

Kim C.-H., Khan M., Morin D., Hurley W., Tripathy D., Kehrli Jr M., Oluoch A. \& Kakoma I. 2001. Optimization of the PCR for detection of Staphylococcus aureus nuc gene in bovine milk. J. Dairy Sci. 84:74-83.

Krewer C.C., Amanso E.S., Gouveia G.V., Souza R.L., Da Costa M.M. \& Mota R.A. 2014. Resistance to antimicrobials and biofilm formation in Staphylococcus spp. isolated from bovine mastitis in the Northeast of Brazil. Trop. Anim. Health Prod. 47:511-518.

Lange C.C., Brito M.A.V.P., Reis D.R.L., Machado M.A., Guimarães A.S., Azevedo A.L.S., Salles É.B., Alvim M.C.T., Silva F.S. \& Meurer I.R. 2015. Species-level identification of staphylococci isolated from bovine mastitis in Brazil using partial 16S rRNA sequencing. Vet. Microbiol. 176:382-388.

Le Loir Y., Baron F. \& Gautier M. 2003. Staphylococcus aureus and food poisoning. Genet. Mol. Res. 2:63-76.

Li G., Wu S., Luo W., Su Y., Luan Y. \& Wang X. 2015. Staphylococcus aureus ST6-t701 Isolates from food-poisoning outbreaks (2006-2013) in Xi'an, China. Foodborne Pathog. Dis. 12:203-206.

Liu Y., Chen W., Ali T., Alkasir R., Yin J., Liu G. \& Han B. 2014. Staphylococcal enterotoxin $\mathrm{H}$ induced apoptosis of bovine mammary epithelial cells in vitro. Toxins 6:3552-3567.

Nazari R., Godarzi H., Rahimi Baghi F. \& Moeinrad M. 2014. Enterotoxin gene profiles among Staphylococcus aureus isolated from raw milk. Iran. J. Vet. Res. 15:409-412.
Necidová L., Štástková Z., Pospíšilová M., Janštová B., Strejček J., Dušková M. \& Karpíšková R. 2009. Influence of soft cheese technology on the growth and enterotoxin production of Staphylococcus aureus. Czech J. Food Sci. 27:127-133.

Ote I., Taminiau B., Duprez J.-N., Dizier I. \& Mainil J.G. 2011. Genotypic characterization by polymerase chain reaction of Staphylococcus aureus isolates associated with bovine mastitis. Vet. Microbiol. 153:285-292.

Perillo J., Ceccarelli D., Spagnoletti M., Lollai S., Cappuccinelli P. \& Colombo M.M. 2012. Molecular characterization of enterotoxigenic and borderline oxacillin resistant Staphylococcus strains from ovine milk. Food Microbiol. 32:265-273.

Prince L.R., Graham K.J., Connolly J., Anwar S., Ridley R., Sabroe I., Foster S.J. \& Whyte M.K. 2012. Staphylococcus aureus induces eosinophil cell death mediated by $\alpha$-hemolysin. PloS One 7:e31506.

Rall V., Vieira F., Rall R., Vieitis R., Fernandes A., Candeias J., Cardoso K. \& Araújo J. 2008. PCR detection of staphylococcal enterotoxin genes in Staphylococcus aureus strains isolated from raw and pasteurized milk. Vet. Microbiol. 132:408-413.

Rall V.L.M., Miranda E.S., Castilho I.G., Camargo C.H., Langoni H., Guimarães F.F., Araújo Júnior J.P. \& Fernandes Júnior A. 2014. Diversity of Staphylococcus species and prevalence of enterotoxin genes isolated from milk of healthy cows and cows with subclinical mastitis. J. Dairy Sci. 97:829-837.

Rao R., Nagarkatti P. \& Nagarkatti M. 2014. Staphylococcal enterotoxin B-induced MicroRNA-155 Targets SOCS1 to promote acute inflammatory lung injury. Infect. Immun. 82:2971-2979.

Reis A.L., Montanhini M., Bittencourt J.V., Destro M.T. \& Bersot L.S. 2013. Gene detection and toxin production evaluation of hemolysin BL of $\mathrm{Ba}$ cillus cereus isolated from milk and dairy products marketed in Brazil. Braz. J. Microbiol. 44:1195-1198.

Ruaro A., Andrighetto C., Torriani S. \& Lombardi A. 2013. Biodiversity and characterization of indigenous coagulase-negative staphylococci isolated from raw milk and cheese of North Italy. Food Microbiol. 34:106111.

Saei H.D., Ahmadi M., Mardani K. \& Batavani R.A. 2009. Molecular typing of Staphylococcus aureus isolated from bovine mastitis based on polymorphism of the coagulase gene in the north west of Iran. Vet. Microbiol. 137:202-206.

Salasia S.I.O., Tato S., Sugiyono N., Ariyanti D. \& Prabawati F. 2011. Genotypic characterization of Staphylococcus aureus isolated from bovines, humans, and food in Indonesia. J. Vet. Sci. 12:353-361.

Salgado-Ruiz T.B., Rodríguez A., Gutiérrez D., Martínez B., García P., Espinoza-Ortega A., Martínez-Campos A.R., Lagunas-Bernabé S., Vicente F. \& Arriaga-Jordán C.M. 2014. Molecular characterization and antimicrobial susceptibility of Staphylococcus aureus from small-scale dairy systems in the highlands of Central México. Dairy Sci. Technol. 95:181-196.

Silveira-Filho V.M., Luz I.S., Campos A.P. F., Silva W.M., Barros M.P. S., Medeiros E.S., Freitas M.F. L., Mota R.A., Sena M.J. \& Leal-Balbino T.C. 2014. Antibiotic resistance and molecular analysis of Staphylococcus aureus isolated from cow's milk and dairy products in Northeast Brazil. J. Food Protect. 77:583-591.

Singh M., Singh A. \& Sharma A. 2014. Production and applications of an N-terminally-truncated recombinant beta-haemolysin from Staphylococcus aureus. Biologicals 42:191-198.

Veras J.F., Do Carmo L.S., Tong L.C., Shupp J.W., Cummings C., Dos Santos D.A., Cerqueira M.M.O.P., Cantini A., Nicoli J.R. \& Jett M. 2008. A study of the enterotoxigenicity of coagulase-negative and coagulase-positive staphylococcal isolates from food poisoning outbreaks in Minas Gerais, Brazil. Int. J. Infect. Dis. 12:410-415.

Wang S.-C., Wu C.-M., Xia S.-C., Yong-Hua Q., Xia L.-N. \& Shen J.-Z. 2009. Distribution of superantigenic toxin genes in Staphylococcus aureus isolates from milk samples of bovine subclinical mastitis cases in two major diary production regions of China. Vet. Microbiol. 137:276-281.

Yang F.L., Li X.S., Liang X.W., Zhang X.F., Qin G.S. \& Yang B.Z. 2012. Detection of virulence-associated genes in Staphylococcus aureus isolated from bovine clinical mastitis milk samples in Guangxi. Trop. Anim. Health Prod. 44:1821-1826. 